\title{
HUBUNGAN MOTIVASI BERPRESTASI DAN DISIPLIN BELAJAR DENGAN PRESTASI BELAJAR STANDAR KOMPETENSI MENGGUNAKAN ALAT- ALAT UKUR PADA SISWA KELAS XI SMK TRISAKTI 1 LUBUK PAKAM TAHUN PEMBELAJARAN 2013/2014
}

\author{
Manintin Banjarnahor ${ }^{1}$, Mikhael Sihombing ${ }^{2}$ \\ ${ }^{1}$ Universitas Negeri Medan, ${ }^{2}$ Universitas Negeri Medan \\ ${ }^{1}$ m_banjarnahor@gmail.com, ${ }^{2}$ mikhael.sihombing19@gmail.com
}

\begin{abstract}
Abstrak: Penelitian ini bertujuan untuk mengetahui besarnya hubungan antara Motivasi Berprestasi dan Disiplin Belajar dengan Prestasi Belajar Standar Kompetensi Menggunakan Alat-Alat Ukur pada Siswa Kelas XI SMK Trisakti Lubuk Pakam dengan sampel sebanyak 58 orang. Dengan menggunakan metode deskriptif korelasional, untuk mendapatkan data motivasi berprestasi dan disiplin belajar dilakukan dengan menggunakan angket, sedangkan untuk data prestasi belajar didapat dengan dokumentasi dari nilai siswa setelah mengikuti ujian akhir semester. Sebelum angket digunakan dalam penelitian, terlebih dahulu dilakukan uji coba instrumen penelitian. Uji Signifikansi koefisien korelasi di peroleh nilai $t_{\text {lhitung }}>t_{\text {tabel }}=3,55>1,67$ dan $t_{2 \text { hitung }}>t_{\text {tabel }}=3,34>1,67$ dengan demikian hipotesis yang berbunyi terdapat hubungan yang signifikan antara motivasi berprestasi dan disiplin belajar dengan prestasi belajar standar kompetensi menggunakan alat-alat ukur siswa kelas XI SMK I Trisakti Lubuk Pakam teruji kebenarannya.
\end{abstract}

Kata Kunci: Motivasi Berprestasi, Disiplin Belajar dan Prestasi Belajar

\begin{abstract}
This research aims to know the magnitude of the relationship between Motivation and Learning Discipline Achievers with Learning Achievement Standards of competence to use Measuring tools on Grade XI SMK Trisakti Lubukpakam with samples as many as 58 people. By using descriptive method korelasional, To get the data the motivation of learning discipline and achievers is done using the now, as for the learning achievements acquired data with documentation of the value students after the end of the semester examination. Before the now used in research, first conducted trials research instrument. Test of the significance of the correlation coefficient in the get the value $t_{\text {lhitung }} t>_{\text {tables }}=$ 3.551 .67 and $t>_{\text {2hitung }}>t=$ table $3.34>1.67$ thus the hypothesis that says there is a significant relationship between motivation and learning discipline achievers with learning competency standard achievements using tools measure the grade XI SMK Trisakti Lubukpakam I tested truth.
\end{abstract}

Keywords: Motivation and Learning Discipline Achievers with Learning Achievement.

\section{PENDAHULUAN}

Sekolah Menengah Kejuruan (SMK) adalah suatu lembaga pendidikan formal yang memberi bekal pengetahuan teknologi, keterampilan, sikap disiplin dan etos kerja tingkat menengah yang terampil dan kreatif. Ditekankan lagi dalam GarisGaris Besar Program Pendidikan dan Pelatihan (GBPP) Kurikulum SMK Edisi 2004 sebagaiman ditegaskan dalam penjelasan pasal 1 UndangUndang Tentang Sistem Pendidikan Nasional tahun 2003, yakni bahwa:

"Pendidikan adalah usaha sadar dan terencana dapat dikategorikan lulus, dengan standar ketuntasan untuk mewujudkan suasana belajar dan proses Ukur 7,0. Dari data tersebut dapat disimpulkan bahwa pembelajaran agar peserta didik secara aktif prestasi belajar Standar Kompetensi menggunakan mengembangkan potensi dirinya untuk memiliki Alat-Alat Ukur siswa kelas XI Teknik Kendaraan kekuatan spiritual keagamaan, pengendalian diri, Ringan SMK I TRISAKTI Lubuk Pakam masih kepribadian, kecerdasan, akhlak mulia, serta belum sesuai dengan apa yang diharapkan.

keterampilan yang diperlukan dirinya, masyarakat, bangsa dan negara."

Dari kutipan di atas dapat dikatakan bahwa siswa Sekolah Menengah Kejuruan (SMK) diarahkan untuk mengembangkan suatu sistem yang utuh dan mantap sehingga siswa akan dapat berhasil dan siap pakai dalam bidangnya masing-masing dan dapat menjadi warga negara yang produktif.

\section{KERANGKA TEORITIS}

\section{Hakikat Motivasi Berprestasi}

Berprestasi adalah merupakan suatu keadaan yang dialami sesorang dalam melakukan kegiatan.Berarti seseorang dikatakan berprestasi apabila pada dirinya terjadi perubahan dari suatu 
keadaan terhadap keadaan yang lebih baik.Terjadinya perubahan itu dipengaruhi oleh beberapa faktor yang datang dari dalam diri individu maupun yang datang dari luar individu itu sendiri. Salah satu faktor tersebut adalah motivasi, yang secara langsung menggerakkan individu melaksanakan kegiatan untuk mencapai tujuan tertentu.

Setiap tingkah laku yang ditampilkan biasanya didahului oleh adanya suatu motivasi, dan motivasi itu dapat dikatakan sebagai penentu tingkah laku. Motivasi berasal dari kata movere yang mempunyai arti menggerakkan, mengendalikan, membangkitkan kegiatan-kegiatan, menumbuhkan perasaan, mengambil prakarsa dan usaha mencapai tujuan yang diinginkan Purba (2000 : 61). Motif adalah semua penggerak, alasan-alasan atau dorongan-dorongan dalam diri manusia yang menyebabkan ia berbuat sesuatu (Gerungan, 1996 : 140). Pendapat ini menjelaskan bahwa motif dapat dikatakan sebagai daya penggerak dalam diri sesorang dan bersemangat dalam melakukan aktivitas-aktivitas tertentu untuk mencapai suatu tujuan.

Berdasarkan uraian di atas dapat disimpulkan bahwa motivasi berprestasi merupakan pembangkit kekuatan yang mendorong seseorang untuk melakukan kegiatannya yang berhubungan dengan pencapaian tujuan pembelajaran sehingga seseorang tersebut akan mencapai prestasi tersebut.

\section{Hakikat Disiplin Belajar}

Perkataan disiplin bukan merupakan hal yang baru bahkan sudah sering didengar dalam kehidupan sehari-hari dan saat ini menjadi satu program pemerintah seperti gerakan disiplin nasional. Perkataan disiplin sering dikaitkan dengan tata tertib atau perkataan yang harus ditaati. Menurut Poerwadarminto, (1995 : 254) dalam kamus besar bahasa Indonesia, pengertian disiplin: (1) tata tertib (2) ketaatan atau kepatuhan pada peraturan atau tata tertib.

Wibisono (1983 : 25) mengemukakan bahwa disiplin itu ada dua pengertian yaitu disiplin diri dan disiplin sosial. Seorang individu dikatakan memiliki disiplin diri jika ia mampu menggerakkan tingkah lakunya, jika tidak, berarti tidak dikatakan disiplin.

Untuk dapat memperoleh hasil yang lebih baik dalam mencapai tujuan tertentu dibutuhkan pengendalian diri. Mengendalikan diri berarti dapat menahan diri dari perbuatan-perbuatan yang tidak sesuai dengan aturan yang berlaku. Dengan jalan mengendalikan diri kita terhindar dari kelakuan yang tidak berguna bagi diri kita terutama dalam meningkatkan prestasi belajar.

Dari uraian di atas, dapat disimpulkan bahwa disiplin belajar adalah kepatuhan siswa terhadap peraturan, pengendalian diri dalam belajar, perilaku tertib atau karakter dalam belajar, efisien dalam penggunaan waktu dan mempersiapkan diri siswa dalam belajar.

\section{Hakikat Prestasi Belajar Standar Kompetensi Menggunakan Alat-Alat Ukur}

Belajar merupakan salah satu faktor yang mempengaruhi dan berperan penting dalam pembentukan pribadi dan perilaku individu. Sukamdinata (2005) menyebutkan bahwa sebagian besar perkembangan individu berlangsung melalui kegiatan belajar. Menurut Anni (2004), belajar merupakan proses perolehan kemampuan yang berasal dari pengalaman. Sedangkan menurut Winataputra (2008) pengertian belajar adalah proses yang dilakukan oleh manusia untuk mendapatkan aneka ragam competencies, skills, and attitude. Kompetensi tersebut berupa kemampuan (competencies), keterampilan (skills), dan sikap (attitude).

Sutikno (2007) mengemukakan pengertian belajar adalah suatu proses atau usaha yang dilakukan oleh seseorang untuk memperoleh suatu perubahan yang baru sebagai hasil pengalamannya sendiri dalam interaksinya dengan lingkungan sekitarnya. Menurut paradigma behavioristik belajar merupakan transmisi pengetahuan dari expert novice. Berdasarkan konsep ini, bahwasanya belajar merupakan interaksi antara pelajar (siswa) dan pengajar (guru) berupa transfer pengetahuan. Peran guru dalam hal ini menyediakan dan menuangkan informasi/pengetahuan sebanyak-banyaknya kepada siswa. Sedangkan menurut paham konstruktivistik, belajar merupakan hasil konstruksi sendiri (pebelajar) sebagai hasil interaksinya terhadap lingkungan belajar. Pengkonstruksian pemahaman dalam ivent belajar dapat melalui proses asimilasi atau akomodasi.

Prestasi belajar dihasilkan setelah seseorang melakukan kegiatan seperti yang dikatakan oleh Djamarah (1994) bahwa: "Prestasi adalah hasil dari suatu kegiatan yang telah dikerjakan, diciptakan, baik secara individual maupun kelompok". Sementara menurut Poerwadarminta (1988) bahwa: "Prestasi adalah hasil yang dicapai, dikerjakan dan sebagainya". Sedangkan menurut Djamarah (1994) bahwa: "Prestasi adalah diciptakan, hasil pekerjaan, hasil yang menyenangkan hati yang diperoleh dengan keuletan kerja”.

Menurut Bahri (1994) bahwa: "Prestasi belajar adalah penilaian atas hasil kegiatan belajar siswa. Dimana penilaian adalah sebagian aktivitas dalam menentukan tinggi rendahnya prestasi belajar itu sendiri dan untuk menentukan tinggi rendahnya prestasi belajar itu sendiri dan untuk menentukan segala sesuatu dalam pendidikan maka perlu evaluasi.

Dari berbagai uraian di atas dapat disimpulkan bahwa prestasi belajar Standar Kompetensi Menggunakan Alat-Alat Ukur adalah tingkat 
pencapaian yang diperoleh siswa setelah Hubungan Antara Disiplin Belajar dengan melakukan kegiatan belajar Menggunakan Alat- Prestasi Belajar Standar Kompetensi Alat Ukur, berupa kemampuan kognitif, afektif, Menggunakan Alat-Alat Ukur

dan psikomotorik dan dinyatakan dalam bentuk Disiplin merupakan sebagian dari proses belajarangka, huruf atau kata-kata baik, sedang dan mengajar. Disiplin yang tercipta di sekolah kurang.

\section{KERANGKA BERPIKIR}

Hubungan Antara Motivasi Berprestasi dengan Prestasi Belajar Standar Kompetensi Menggunakan Alat-Alat Ukur

Untuk mencapai suatu prestasi belajar yang baik bagi siswa, diperlukan usaha-usaha yang dapat menggiatkan siswa tersebut dapat belajar lebih sungguh-sungguh dengan cara positif yang juga merupakan langkah motivasi berprestasi. Pada dasarnya setiap keberhasilan dalam pencapaian tujuan belajar tidak lepas dari besar kecilnya motivasi berprestasi yang berhubungan dengan pencapaian prestasi belajar siswa.

Motivasi adalah sebagai suatu pendorong (baik yang berasal dari dalam diri sendiri/intrinsik, maupun dari luar/ekstrinsik), yang mengubah energi dalam diri seseorang ke dalam bentuk aktivitas nyata untuk mencapai tujuan tertentu.

Slameto (1991 : 101) mengatakan bahwa tinggi rendahnya prestasi belajar banyak ditentukan oleh besar kecilnya motivasi untuk berprestasi. Hal ini berarti siswa yang mempunyai motivasi untuk berprestasi yang besar akan mempunyai hasil belajar yang tinggi. Dengan demikian diduga bahwa semakin besar motivasi untuk berprestasi pada Standar Kompetensi Menggunkan Alat-Alat Ukur, maka prestasi belajar Standar Kompetensi Menggunkan Alat-Alat Ukur semakin tinggi.

Dari uraian di atas dapat disimpulkan bahwa motivasi berprestasi adalah kondisi psikologis yang mendorong seseorang untuk berprestasi, melakukan kegiatan belajar dengan mengerjakan tugas, serta harapan dan perasaan untuk memperoleh penghargaan.

Prestasi belajar adalah hasil psikis yang menunjukkan sikap keyakinan serta perasaan yang mendorong siswa untuk berbuat pada Standar Kompetensi Menggunakan Alat-Alat Ukur. Prestasi belajar yang baik timbul bila rangsangan atau proses pendidikan dan latihan diarahkan pada pencapaian hasil dan mutu yang sempurna. Dengan motivasi berprestasi yang tinggi, maka akan dapat mendorong siswa untuk belajar dengan giat untuk mendapatkan hasil belajar yang baik pula. Dan seorang siwa yang memiliki motivasi berprestasi yang besar akan membuahkan hasil belajar yang baik.

Sehubungan dengan hal tersebut, maka dapat diduga bahwa semakin tinggi motivasi berprestasi siswa, semakin tinggi prestasi belajar Standar Kompetensi menggunakan Alat-Alat Ukur. merupakan suatu keadaan tata tertib di lingkungan sekolah yang disebabkan adanya upaya dari semua pihak yang ada di dalam sekolah itu untuk menuruti peraturan-peraturan yang telah disepakati. Kedisiplinan suatu sekolah sangat berkaitan dengan kelancaran proses belajar-mengajar karena tanpa disiplin tidak akan ada kesepakatan antara guru dan siswa serta hasil pembelajaran tidak sesuai dengan yang diharapkan. Siswa yang dikatakan berdisiplin jika ia mampu mengarahkan tingkah lakunya sesuai dengan kebutuhannya selaras pula dengan aturanaturan yang berlaku di sekolah baik yang tertulis maupun yang tidak tertulis.

Disiplin belajar yang baik akan membuat siswa dapat mengendalikan dirinya untuk belajar lebih baik, lebih giat, lebih tenang dan dapat menggunakan waktu yang ada dengan baik untuk belajar secara terus menerus.

Dengan demikian, dapat disimpulkan bahwa disiplin belajar sangat berhubungan dengan prestasi belajar siswa. Dengan adanya disiplin belajar akan mempermudah dan memperlancar proses belajarmengajar dan dengan sendirinya prestasi belajar akan lebih mudah dicapai, sehingga dapat diduga bahwa semakin tinggi disiplin belajar siswa, semakin tinggi pula prestasi belajar Standar Kompetensi Menggunakan Alat-Alat Ukur.

\section{Hubungan Antara Motivasi Berprestasi dan Disiplin Belajar dengan Prestasi Belajar Standar Kompetensi Menggunakan Alat-Alat Ukur}

Dengan adanya motivasi berprestasi dalam diri siswa, akan mendorong siswa tersebut untuk belajar lebih sungguh-sungguh dengan cara positif. Disiplin belajar akan membuat siswa dapat mengendalikan dirinya untuk belajar lebih baik, lebih giat, lebih tenang dan dapat menggunakan waktu yang ada dengan baik untuk belajar secara terus-menerus. Dengan disiplin yang baik seorang siswa dapat belajar dengan teratur dan sungguh-sungguh, sehingga motivasi berprestasi yang besar pada diri siswa diyakini dapat membantu tercapainya hasil belajar yang tinggi. Dengan demikian dapat diduga bahwa semakin tinggi motivasi berprestasi dan disiplin belajar, semakin tinggi pula prestasi belajar siswa pada Standar Kompetensi Menggunakan Alat-Alat Ukur.

\section{HIPOTESIS}

Berdasarkan landasan teoritis dan landasan berpikikir yang telah dijelaskan di atas dapat diajukan beberapa hipotesis yang perlu untuk diuji kebenarannya dalam penelitian ini, yaitu sebagai berikut:

1. Terdapat hubungan yang positif dan berarti antara motivasi berprestasi $\left(\mathrm{X}_{1}\right)$ dengan prestasi belajar 
mata diklat Menggunakan Alat-ALat Ukur (Y) pada siswa kelas XI Teknik Kendaraan Ringan SMK I Trisakti Lubuk Pakam.

2. Terdapat hubungan yang positif dan berarti antara disiplin belajar $\left(\mathrm{X}_{2}\right)$ dengan prestasi belajar mata diklat Menggunakan Alat-ALat Ukur (Y) siswa kelas XI Teknik Kendaraan Ringan SMK I Trisakti Lubuk Pakam.

3. Terdapat hubungan yang positif dan berarti antara motivasi berprestasi $\left(\mathrm{X}_{1}\right)$ dan disiplin belajar $\left(\mathrm{X}_{2}\right)$ dengan prestasi belajar mata diklat Menggunakan Alat-ALat Ukur (Y) pada siswa kelas XI Teknik Kendaraan Ringan SMK I Trisakti Lubuk Pakam.

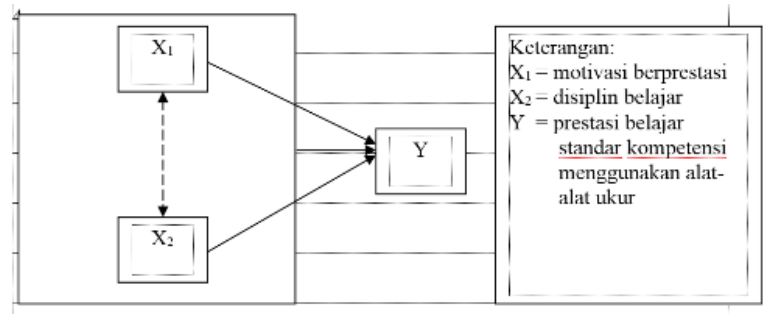

Gambar 1. Paradigma Penelitian

\section{METODOLOGI PENELITIAN}

Berdasarkan tujuan dari penelitian ini, yakni mencari hubungan antara motivasi berprestasi dengan prestasi belajar Standar Kompetensi Menggunakan Alat-ALat Ukur, mencari hubungan antara disiplin belajar dengan prestasi belajar Standar Kompetensi Menggunakan Alat-ALat Ukur dan mencari hubungan antara motivasi berprestasi dan disiplin belajar dengan prestasi belajar Standar Kompetensi Menggunakan Alat-ALat Ukur. Maka metode yang digunakan adalah metode deskriptif korelasional, yaitu penelitian yang bertujuan untuk menyelidiki kenyataan yang telah terjadi sebagaimana adanya berdasarkan fakta-fakta yang ada untuk menguji serangkaian hipotesis.

\section{Variabel Penelitian}

Dalam penelitian ini ada tiga variabel, terdiri dari dua variabel bebas dan satu variabel terikat. Variabel bebas yaitu motivasi berprestasi $\left(\mathrm{X}_{1}\right)$ dan disiplin belajar $\left(\mathrm{X}_{2}\right)$. Variabel terikat yaitu prestasi belajar menggunakan alat-alat ukur (Y). Hubungan dalam penelitian ini dapat digambarkan sebagai berikut:

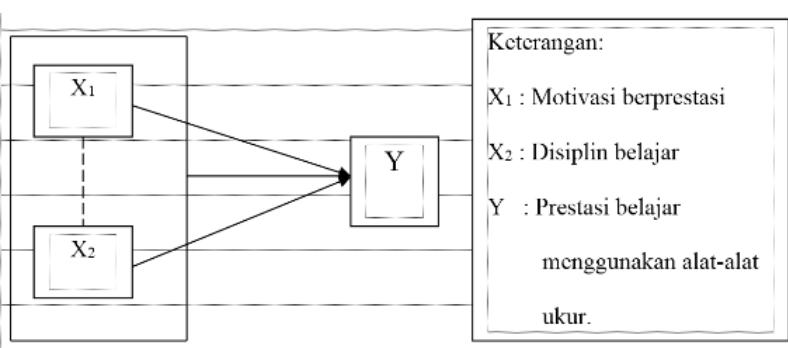

Gambar 2. Hubungan Variabel

\section{HASIL DAN PEMBAHASAN PENELITIAN}

Temuan Penelitian
Berdasarkan hasil yang diperoleh dari analisis deskriptif dan setelah diadakan pengujianpengujian, maka secara umum ditemukan Motivasi Berprestasi siswa SMK I Trisakti Lubuk Pakam kelas XI Kompetensi Keahlian Teknik Kendaraan Ringan (cenderung cukup), Motivasi Berprestasi siswa SMK I Trisakti Lubuk Pakam Kelas XI Kompetensi Keahlian Teknik Kendaraan Ringan (cenderung cukup), Disiplin Belajar siswa SMK I Trisakti Lubuk Pakam Kelas XI Kompetensi Keahlian Teknik Kendaraan Ringan (cenderung cukup).

Hasil penelitian ini mengungkapkan bahwa : 1) Terdapat hubungan yang positif dan berarti antara Motivasi Berprestasi dengan Prestasi Belajar Standar Kompetensi Menggunakan Alat-Alat Ukur pada Siswa Kelas XI SMK I Trisakti Lubuk Pakam . 2) Terdapat hubungan yang positif dan berarti antara Disiplin Belajar dengan Prestasi Belajar Standar Kompetensi Menggunakan Alat-Alat Ukur pada Siswa Kelas XI SMK I Trisakti Lubuk Pakam. Terdapat hubungan yang positif dan berarti antara Motivasi Berprestasi dan Disiplin Belajar dengan Prestasi Belajar Standar Kompetensi Menggunakana Alat-Alat Ukur pada Siswa Kelas XI SMK I Trisakti Lubuk Pakam.

\section{Pembahasan Penelitian}

Hasil penelitian ini mengungkapkan terdapat hubungan motivasi berprestasi dan disiplin belajar dengan prestasi belajar standar menggunakan alatalat ukur. Hal ini memberikan arti semakin tinggi motivasi dan disiplin belajar siswa maka akan semakin tinggi prestasi belajar standar kompetensi menggunakan alat-alat ukur, hal ini sesuai dengan hasil penelitian yang dilakukan di SMK I Trisakti Lubuk Pakam. Tetapi sebelum angket disebarkan, terlebih dahulu instrument diujicobakan kepada 58 orang siswa yang sama dengan responden untuk melihat validitas dan relibilitas instrument, dari 39 butir angket yang diujicobakan ternyata 30 butir angket yang dinyatakan valid, sedangkan relibilitasnya sebesar 0,732 untuk angket motivasi berprestasi, 30 butir angket valid dari 41 butir angket dengan relibilitas 0,776 untuk angket disiplin belajar.

Dari hasil korelasi sederhana dikemukakan hubungan yang positif antara motivasi berprestasi dan disiplin belajar dengan prestasi belajar standar kompetensi menggunakan alat-alat ukur. Hal ini dapat terlihat dari korelasi yang memberikan nilai koefisien korelasi antara motivasi berprestasi dengan prestasi belajar $r_{x y 1}$ sebesar 0,372 dibandingkan dengan $\mathrm{r}_{\text {tabel }}=0,254$ dan nilai korelasi antara disiplin belajar dengan prestasi belajar $\mathrm{r}_{\mathrm{xy} 2}$ sebesar 0,364 dibandingkan dengan $r_{\text {tabel }}=0,254$.

Hasil korelasi kemudian diuji dengan hipotesis menggunakan uji $t$, hasil perhitungannya menunjukkan bahwa $t_{1 h i t u n g}=3,3120$ sedangkan $t_{\text {tabel }}$ $=1,67$ dan $t_{2 h i t u n g}=3,2468$ sedangkan $t_{\text {tabel }}=1,67$, 
dengan demikian hipotesis yang berbunyi Muhibbinsyah. (1995). Psikologi Penelitian Suatu "Terdapat hubungan yang positif dan signifikan dalam motivasi berprestasi dan disiplin belajar Pendekatan Baru. Bandung. Remaja

dengna prestasi belajar standar kompetensi Mardalis. (1989). Interaksi dan Motivasi Belajar menggunakan alat-alat ukur siswa kelas XI SMK I Mengajar, Jakarta. PT. Raja Grafindo Trisakti Lubuk Pakam" teruji kebenarannya.

\section{PENUTUP}

Napitupulu. (1988). Belajar Dan Pembelajaran, . Medan. Unimed.

Berdasarkan hasil penelitian yang telah diuraikan pada bab IV, maka kesimpulan penelitian ini adalah sebagai berikut:

1. Tingkat kecenderungan motivasi berprestasi dari siswa Kelas XI Kompetensi Keahlian Teknik Kendaraan Ringan SMK Trisakti I Lubuk Pakam T.A. 2013/2014 cenderung cukup.

Poerbakawakja. (1985). Konsep dan Makna Pembelajaran. Jakarta: Alfabeta.

\section{Tesis/Disertasi/Seminar/Proceeding:}

Smith A.B. (1999). Anlysis of interaction process and sociometric relatins developed during theraphy with offenders on probation. :Unpublished doctoral dissertations. New York: New York University.

2. Tingkat kecenderungan disiplin belajar dari Poerwadarminto. (1995). Kamus Umum Bahasa siswa Kelas XI Kompetensi Keahlian Teknik Kendaraan Ringan SMK Trisakti I Lubuk Pakam T.A. 2013/2014 cenderung cukup. Indonesia. Jakarta. PN Balai Pustaka. Sumber Online:

3. Tingkat kecenderungan prestasi belajar dari siswa Kelas XI Kompetensi Keahlian Teknik Pudjijogyant. (2007). Peluang Kerja Lulusan SMK, Kendaraan Ringan SMK Trisakti I Lubuk Pakam T.A. 2013/2014 cenderung cukup.

4. Terdapat hubungan yang positif dan berarti antara motivasi berprestasi dengan prestasi belajar dari siswa Kelas XI Kompetensi Keahlian Teknik Kendaraan Ringan SMK Trisakti I Lubuk Pakam T.A. 2013/2014.

5. Terdapat hubungan yang positif dan berarti antara disiplin belajar dengan prestasi belajar dari siswa Kelas XI Kompetensi Keahlian Teknik Kendaraan Ringan SMK Trisakti I Lubuk Pakam T.A. 2013/2014.

6. Terdapat hubungan yang positif dan berarti antara motivasi berprestasi dan disiplin belajar dengan prestasi belajar dari siswa Kelas XI Kompetensi Keahlian Teknik Kendaraan Ringan SMK Trisakti I Lubuk Pakam T.A. 2013/2014.

\section{DAFTAR PUSTAKA}

Anni. (2004). Psikologi Umum. Jakarta: PT. Rineka Cipta.

Arikunto, S. (2002). Prosedur Penelitian Suatu Pendekatan Praktek. Jakarta: PT. Rineka Cipta.

Arsyad (2002). Quantum Learning (Membiasakan Belajar Nyaman dan Menyenangkan). Bandung: Kaifah.

Budingningsih. (2005). Pendidikan dan Masalahnya. Jakarta: FIP.

Gellerman. (1998). Ensikolpedia Umum..

Gerungan (1996). Pengolahan Data Secara Statistik. Jakarta: Fakultas Pascasarjana IKIP Jakarta

Kartono, K. (1985). Teori kependidikan, Bandung. Alumni.

Mc Clelleand.(1985). Pengolahan Data Secara Statistik, Jakarta. Fakultas Pasca Sarjana IKIP Jakarta. 